\title{
Erratum to: Tongue squamous cell carcinoma producing both parathyroid hormone-related protein and granulocyte colony-stimulating factor: a case report and literature review
}

\author{
Naoki Kaneko ${ }^{1}$, Shintaro Kawano ${ }^{1 *}$, Ryota Matsubara ${ }^{1}$, Yuichi Goto ${ }^{1,2}$, Teppei Jinno ${ }^{1}$, Yasuyuki Maruse ${ }^{1}$
} Taiki Sakamoto ${ }^{1}$, Yuma Hashiguchi ${ }^{1}$, Masakazu lida ${ }^{1}$ and Seiji Nakamura ${ }^{1}$

\section{Erratum}

After publication of the original article [1] it was brought to our attention that the funding information was not correctly reflected in the article.

The original Funding information contains an incorrect number. The original sentence reads as:

This work was supported by a Grant-in-Aid (26463014, 60615798, and 26670869) from the Japanese Ministry of Education, Culture, Sports, Science and Technology.

The revised sentence, with the correct number reads as follows:

This work was supported by a Grant-in-Aid (26463014, 26861729, and 26670869) from the Japanese Ministry of Education, Culture, Sports, Science and Technology.

Please note that the number 60615798 should instead be 26861729 .

\footnotetext{
Author details

'Section of Oral and Maxillofacial Oncology, Division of Maxillofacial Diagnostic and Surgical Sciences, Faculty of Dental Science, Kyushu University, 3-1-1 Maidashi, Higashi-ku, Fukuoka 812-8582, Japan. ${ }^{2}$ Maxillofacial Diagnostic and Surgical Science, Department of Oral and Maxillofacial Rehabilitation, Course for Developmental Therapeutics, Kagoshima University Graduate School of Medical and Dental Sciences, 8-35-1 Sakuragaoka, Kagoshima 890-8544, Japan.
}

Received: 11 July 2016 Accepted: 11 July 2016 Published online: 19 July 2016

\section{Reference}

1. Kaneko N, et al. Tongue squamous cell carcinoma producing both parathyroid hormone-related protein and granulocyte colony-stimulating factor: a case report and literature review. World J Surg Oncol. 2016;14:161.
* Correspondence: skawano@dent.kyushu-u.ac.jp

${ }^{1}$ Section of Oral and Maxillofacial Oncology, Division of Maxillofacial Diagnostic and Surgical Sciences, Faculty of Dental Science, Kyushu University, 3-1-1 Maidashi, Higashi-ku, Fukuoka 812-8582, Japan

Full list of author information is available at the end of the article
Submit your next manuscript to BioMed Central and we will help you at every step:

- We accept pre-submission inquiries

- Our selector tool helps you to find the most relevant journal

- We provide round the clock customer support

- Convenient online submission

- Thorough peer review

- Inclusion in PubMed and all major indexing services

- Maximum visibility for your research

Submit your manuscript at www.biomedcentral.com/submit 